\title{
TEXTUALIDADES EM MÍDIAS DIGITAIS: ESTÉTICAS INTERMÍDIA E CIBERLITERATURA - APRESENTAÇÃO DOS ORGANIZADORES
}

\author{
Débora Silva* \\ Rui Torres*
}

Considerando-se que os processos de elaboração e divulgação do texto literário e das produções artísticas têm-se alterado substancialmente nas últimas décadas, em especial a partir do advento da Internet e da formação das redes sociais de compartilhamento, faz-se necessário uma revisão de conceitos e uma reconstrução de sentidos que deem conta das novas configurações do discurso literário na contemporaneidade, marcado pela interação de linguagens, no contexto das hipermídias. É assim que a Revista Texto Digital apresenta este Dossiê temático, intitulado "Textualidades em mídias digitais: estéticas intermídia e ciberliteratura", que tem como objetivo delinear os percursos metodológicos para o estudo da produção e da recepção de literatura eletrônica, das artes e mídias interativas.

Este número suscita, portanto, uma discussão sobre os aspectos estilísticos do texto literário em formato digital, tais como a visualidade, a materialidade e a reversibilidade das produções em Literatura Gerada por Computador, as especificidades da linguagem do pixel, da imagineria e dos recursos de hipermídia utilizados nas (re)criações da ciberliteratura. Busca, igualmente, contemplar os procedimentos implicados no processo de escrita e leitura do texto eletrônico: a transposição de códigos, a relação intersemiótica e a dimensão multimidiática da ciberliteratura, sobretudo das poéticas digitais. Nesse contexto, focaliza, em especial, a produção literária lusófona contemporânea, em seus eixos temático, estético e ideológico.

\footnotetext{
*Universidade Estadual de Goiás. Imeio: desants@uol.com.br.

Universidade Fernando Pessoa. Imeio: rtorres@ufp.edu.br. 
O primeiro artigo, Para compreender a Ciberliteratura, de Lúcia Santaella, busca iniciar o leitor nos labirintos do ciberespaço, numa definição elucidativa da ciberliteratura. Assinala a autora que, pela conjunção das mídias digitais, a configuração da literatura sofreu um salto qualitativo em todos os seus aspectos, uma vez que o espaço virtual gerado pelas redes de computadores funciona como um novo meio. Abre-se com ele uma miríade de oportunidades que expandem o conceito de literatura em função da emergência de novas formas de criação literária. Disso decorre que a criação, a teoria e a crítica literárias exigem a redefinição de seus paradigmas herdados da era de Gutenberg. Tendo isso em vista, o texto de Santaella volta-se para a construção textual e hipertextual no espaço digital, o que implica uma exploração do que é ciberliteratura e das peculiaridades que a envolvem: como se aproxima e se distancia da literatura impressa, que estratégias significantes a caracterizam e como essas estratégias são interpretadas pelos usuários, na sua busca de significado.

Na sequência, em Linguagens e Hibridismo, Maria Eugênia Curado apresenta uma breve exposição sobre as múltiplas linguagens e as possibilidades de hibridização nos processos criativos, fundamentando-se nas proposições de Peirce e Santaella. Defendendo o argumento de que todas as linguagens são híbridas, a autora sugere, à luz da teoria das matrizes da linguagem e do pensamento, uma aplicação das matrizes sonora, visual e verbal na linguagem cinematográfica. Para tal, examina duas sequências do filme $A$ hora da estrela, de Suzana Amaral, baseado na obra homônima de Clarice Lispector.

Já em seu texto Média digitais: novos terrenos para a expansão da textualidade, Pedro Reis tece suas considerações sobre a intersecção da literatura com a informática, com especial atenção aos poemas animados por computador, acentuando a tendência do texto para transpor os limites convencionais, ao intensificar as propostas de interpenetração do verbal com o sonoro e o visual, já presentes em manifestações anteriores - como por exemplo, na poesia experimental - mas acentuadas por transformações de maior alcance na literatura digital, caracterizada por textos mais interativos. 
Assim, o autor defende que esse novo espaço eletro-estético parece constituir um incentivo para renovar a interpenetração de códigos de representação: o legível, o visível e o audível, sujeitando a elaboração do texto a uma série de operações algorítmicas, transformações cromáticas ou deformações que podem quebrá-lo, fragmentá-lo, metamorfoseá-lo. Desta forma, no texto eletrônico, palavra, imagem e som caminham pari passu no sentido de uma integração sinestésica.

No artigo Migrações poéticas e derivações visuais: concretismo, experimentalismo e artes plásticas em Portugal, Eduardo Paz Barroso sinaliza um conjunto de questões no âmbito da poesia portuguesa da segunda metade do século $X X$, destacando a relação da poesia visual com as artes plásticas. Nesta perspectiva, o autor produz uma análise crítica de textos, privilegiando o cruzamento de poéticas visuais, expressões plásticas da linguagem e dinâmicas textuais que exploram a plenitude da palavra, suas manifestações gráficas e suas ressonâncias. O panorama da poesia portuguesa dos anos de 1960, a sistematização dos principais entendimentos críticos dela decorrentes e o espaço ocupado pelos autores comprometidos com a vertente visual constituem outro enfoque do texto de Paz Barroso. O pesquisador destaca também o paralelismo entre obras características da poesia visual e a transposição da pintura em poemas de relevantes escritores, bem como indaga o papel da perspectiva ecfrásica nesta discussão. A influência do concretismo brasileiro em Portugal, sua recepção e repercussão constitui outra dentre as importantes reflexões do ensaio.

Em Poesia em rede: poesia portuguesa em blogs e sítios, texto de Manuel Portela e Rita Grácio, os autores partem de um levantamento do uso de meios eletrônicos em rede para a produção e publicação de poesia em Portugal, considerando tanto a poesia publicada e distribuída digitalmente, quanto a poesia eletrônica em sentido estrito, a poesia que depende de códigos de programação e de aplicações de software específicas. Deste modo, buscam observar de que forma as práticas de escrita têm utilizado o meio digital para criar, publicar e distribuir poesia. Defendem que o espaço de escrita eletrônico oferece um canal e um suporte alternativo ao meio mais dispendioso da 
impressão e distribuição em papel. Além disso, alarga as materialidades da literatura a formas e práticas intermídia que tiram partido das capacidades de convergência dos meios de comunicação, promovidas pela digitalidade. Os autores intentam compreender, ainda, a dinâmica social deste campo literário particular e de suas redes de interação, na medida em que estas refletem, contestam ou transformam o campo literário mais amplo.

Na mesma linha de abordagem teórico-crítica das criações digitais em blogs e páginas da Web, Débora Silva propõe uma leitura das representações da modernidade líquida na obra de Antero de Alda, web-poeta português que produz e dissemina sua poesia em meio digital. $O$ cerne de suas análises, nesse enfoque, são as proposições de Zygmunt Bauman sobre as transformações socioculturais do início do século XXI, quando apresenta e discute o conceito de "modernidade líquida", numa contextualização da literatura eletrônica contemporânea. $O$ artigo desenvolve-se por meio da análise e da interpretação de ciberpoemas disponíveis no sítio do autor, considerando-se as dimensões referencial e simbólica da linguagem poética e das produções hipermídia. Segundo a pesquisadora, o autor, recorrendo à convergência de mídias, elabora suas páginas numa composição dinâmica e multidimensional, ao lançar mão de recursos cine-verbi-voco-visuais que promovem efeitos de alta voltagem estética.

Por sua vez, em seu texto Sustentabilidade e entropia na geração textual variacional: PoemAds - sob o signo da devoração, Rui Torres procede à descrição e contextualização teórica de um conjunto de poemas digitais de sua autoria, realizados com o apoio do motor textual Poemário, concebido pelo autor e programado por Nuno Ferreira, seguindo procedimentos combinatórios e generativos. Este trabalho de literatura eletrônica foi programado a partir da conjugação de vários slogans publicitários, constituindo, dessa forma, uma plagiotropia e uma devoração da publicidade atual. O léxico que alimenta estes processos foi tratado e selecionado a partir de aproximadamente 10.000 anúncios publicitários e propagandísticos em língua portuguesa. 
Fechando o ciclo de proposições críticas deste Dossiê, Antônio Fernandes Júnior, em seu texto Videopoesia, suportes e materialidades em Arnaldo Antunes, desenvolve um breve panorama das transformações ocorridas na história do livro, bem como das práticas de leitura dela decorrentes, que estão intimamente ligadas às mudanças que se dão, não apenas na materialidade física ou virtual do suporte, mas, também, no campo da leitura. Em seguida, o autor procede à análise comparativa de um poema, uma canção e um vídeo-poema de Arnaldo Antunes, demonstrando como a mudança de códigos e suportes interfere na produção de sentidos do texto.

Sendo estas as contribuições de pesquisadores, críticos e poetas convidados a integrar esse Dossiê, agradecemos a participação de todos eles e estendemos aos nossos leitores agora o convite a lerem, discutirem e levarem adiante as interessantes abordagens desse número da Texto Digital, a fim de que a literatura eletrônica tenha aqui mais uma oportunidade de disseminação e fruição.

Texto recebido em 31/10/2012. 